\title{
Assessment of Visitor Preferences and Attendance to Singletrails in the Moravian Karst for the Sustainable Development Proposals
}

\author{
Jitka Fialová $^{1, *(D)}$, David Březina ${ }^{2}$, Nikola Žižlavská ${ }^{1}$, Jakub Michal ${ }^{2}$ (D) and Ivo Machar ${ }^{3}$ (D) \\ 1 Department of Landscape Management, Faculty of Forestry and Wood Technology, Mendel University in \\ Brno, CZ613 00 Brno, Czech Republic \\ 2 Department of Forest and Wood Products Economics and Policy, Faculty of Forestry and Wood Technology, \\ Mendel University in Brno, CZ613 00 Brno, Czech Republic \\ 3 Department of Development and Environmental Studies, Faculty of Science, Palacky University Olomouc, \\ 77147 Olomouc, Czech Republic \\ * Correspondence: jitka.fialova@mendelu.cz; Tel.: +42-0545-134-096
}

Received: 30 May 2019; Accepted: 21 June 2019; Published: 28 June 2019

check for updates

\begin{abstract}
An optional leisure activity in forest areas for mountainbikers is the subject of discussion in this article. Cycling has become a popular leisure time activity, not only in the Czech Republic but internationally. A bicycle offers the user an unparalleled freedom that seems to have great appeal in these globalized, modern times. A singletrail is a narrow single-directional path for mountain bicycles in the landscape, in contrast to the two-lane forest roads mainly intended for the industrial purposes of forest management. The singletrails of Moravský kras (Moravian Karst) are built on the land owned by the Mendel University in Brno (Masaryk Forest Enterprise Krrtiny) near the Jedovnice municipality of the Czech Republic. The aim of the article is to assess the attendance of the area using automatic counters, and to analyse the results, especially according to the illegal transits in the area of interest. The preferences of visitors were evaluated using questionnaires as well. Hypotheses were defined, and the chi-square test and Mann-Whitney testing methods were used to validate or improve them. Separate preferences for men and women were analysed in order to detect the differences or similarities of preferences. According to the results, women notably prefer the medium to easiest level of difficulty of the trails while men mainly prefer the trails of medium difficulty, although they use the most difficult trails too. Contact with nature is important for both the target groups. Training on singletrails is not as important for women as for men, but physical activity is very important to both groups. Women mainly ride on the singletrails for the joy of movement, which they consider to be a more important reason than men. The results of this study will be used to improve the area for mountainbikers as well as singletrail design for newly planned areas. Both human preferences and environmental needs will be taken into account.
\end{abstract}

Keywords: mountain bike; questionnaire; TRAFx Mountain Bike Counter; Masaryk Forest Enterprise Křtiny; Jedovnice municipality; game

\section{Introduction}

Mountain biking has become a popular leisure time activity, not only in the Czech Republic but internationally. These days, people desire to learn as much as possible in the shortest period of time, and for the least amount of money when possible. A bicycle has become a priceless means to fulfil these wishes. It also gives the user an unparalleled freedom that seems to have great appeal in these globalized, modern times. When cycling, the cyclist is interconnected with the surroundings in 
which they move. They move fast, yet they can perceive the surroundings and the locality they are moving through.

The impact on the environment or landscape is without question. One of the most visible effects is the modification of the landscape's structure and quality; the impact of cycling on ecological stability is less visible for the non-professional public [1].

Forest soil compaction in one of the main environmental impacts of mountainbiking activities. As Martin et al. [2] state, narrower tires (cyclocross bike) compact soil more than wider tires (mountain bike), and bicycles have a greater impact to vegetation and soil at low levels of trampling than a hiker. However, at higher levels of trampling, the impacts of hikers and bikers were similar. Aerial imagery may reveal how the impact pattern produced by bikes changes around corners. Hrůza and Zemánek [3] state that the soil profiles near the bike path formation, as compared to the forest stand, manifested a lower humidity, higher compaction, and higher $\mathrm{CO}_{2}$ concentration. By analogy, these conditions can be expected directly below the path formation. The above stated facts may impact not only the growth of the roots, which are located near or just below the bike path, but also their water and nutrient supplies.

Several provisions of the Forest Act [4] stipulate the "dos and don'ts" of visitor behaviour in forests. The right of common forest use entitles visitors to enter forests freely regardless of the ownership or rental relations, and thus to use the recreational function of forests. This has already been incorporated in the forest legislation of the Czech Republic over a long period of time and is respected in all modern legal regulations.

As Flora [5] states, despite its broad scope, the right of common forest use cannot be seen as unlimited, i.e., to be interpreted as a right to do in the forest whatever one wants. The first, and probably the broadest in respect of their number, range of its limitations is directly stipulated in the wording of the Forest Act, namely in Section 19, Paragraph 1, which instructs visitors not to damage forests, nor to disturb the forest environment, and to follow the instructions of the owner or the lessee of the forest and their employees; furthermore, Section 20 contains a catalogue of activities which are forbidden to forest visitors. These include a ban on riding bicycles off the forest roads and marked paths. The law especially treats the right of common forest use in case it shall be realised within a scope of an organised or collective sports event. Such events may only be held on the basis of a notification, which its organiser must submit to the body of public forest administration at least 30 days before the day of the event.

The activities of the tourism industry have been affecting the environment in the long term with a broad scale of very intensive impacts, which the literature usually divides into three ancillary categories: economic impacts (e.g., [6-10]), environmental impacts (e.g., [11-14]), and socio-cultural impacts (e.g., $[15,16])$. Not only do these activities often lead to the degradation of the environment and local culture, but they also damage local resources, both directly and indirectly [17]. This entails a degradation of the sources of tourism per se. If this situation is not remedied, it can reach a point at which tourists will leave for other places, leaving behind a locality of tourism businesses and local inhabitants deprived of a source of their growth $[17,18]$. This development is traditionally connected to the tragedy of the commons [19]. Fortunately, some groups recognised as early as the 1960s that, from a long-term point of view, this turbulent development of tourism brings more losses than profits (not only economic, but mainly environmental and cultural). Therefore, measures diminishing the negative impacts of visitor attendance in the target localities are gradually being adopted by both public institutions and businesses [20,21].

The complex monitoring of tourism and visitor attendance in general aims to provide basic information about the number of visitors, data about the time variability of their arrivals (within a day, a week, months of a year, and seasons), and information about the spatial distribution of visitor arrivals within the target territory [22]. A standard output also contains information about the structure of opinions of the visitors. Recently, visitor arrival monitoring has been one of the main activities in the field of tourism administration of large-scale protected areas [23-26]. 
These days, the advancing level of technologies enables the standard use of devices especially intended for counting various target objects. They can monitor virtually anything moving: pedestrian tourists, cyclists, cross-country skiers, motorbike riders, canoeists, etc. Supposing the combination of devices was chosen appropriately, individual types of tourist in the locality can be distinguished reliably, and their proportional ratio can be determined. The complex monitoring of visitor attendance entails a combination of continuous counting of tourists by field automatic counting devices (of various types, according to the requirements for the counted objects) and regular physical and questionnaire surveys (see e.g., [27]).

Automatic counting using a field counting device allows for the collection of basic information about the number of tourists. Advanced (and more costly) configurations provide information about the types of counted object (e.g., distinguish pedestrians from cyclists) in both directions of their movement. Nowadays, there are several basic technologies which can be used for this purpose [22].

According to Campelo and Mendes [28], like other recreational activities, mountain biking has also become another motive for social networking. Dedicated local or national web forums, blogs, and Facebook are nowadays completely connected through dedicated apps like Endomondo, GPSies, MapMyRide, Runtastic, Sports-tracker, Strava, Wikiloc. Sport-dedicated web sharing services can be a valid, important and cheap tool for managers. Because this information is made public by the users themselves, there is no risk of crossing ethical boundaries. Using these services can help managers and researchers spatialize and interfere use intensity of recreational activities.

Cycling further divides into bicycle touring (which emphasises the products of recreational and educative tours) and cross-country cycling (which puts the emphasis on products targeted on mountain bikes) [29]. Bicycle touring is a type of leisure-time activity which involves travelling on a bicycle. Usually, trekking bicycles, city bicycles, mountain bicycles or road bicycles are used to reach destinations outside the built-up areas in particular. Both paved roads and roads with a natural surface are used. The requirements include an attractive surrounding and the highest safety possible [29].

Terrain cycling represents one of the most popular sports in the Czech Republic and is also a world trend in the field of recreation. Among other reasons, the popularity of terrain cycling is consistent with the appeal of recreation for modern people, more specifically in terms of experiences, playfulness, and adventure, while being environmentally friendly [30].

Since the beginning of terrain cycling in the 1970s, terrain cyclists have taken pride in being called "bikers" as it symbolises their distinction from road cyclists [31].

According to the information on the web pages [32,33] a singletrack is a narrow single-directional path for mountain bicycles in the landscape, in contrast to two-lane forest roads mainly intended for the industrial purposes of forest management. It is distinguished from other pavements and paths by. A singletrack has an exact and proven method of construction. The profile is neither too large with respect to differences in elevation, nor does it have long undulating sections. Singletracks generally have a mostly smooth surface and rolling profile, as well as sections requiring high technical skills with stones or roots. There are often various obstacles too which can make cyclists change direction or pace. Individual routes are divided into sections of varying difficulty and colour-coded in the same way as slopes for alpine skiing (green, blue, red, and black from the least to the most difficult), which allows the riders to prepare a route according to their abilities in advance.

Hirano [34] claims that mountain bikers in Japan were socially isolated and, being aware of this social isolation, in the 21st century, some mountain bikers have begun projects to set up and maintain their trails through working with local societies. The research confirms that bikers have even become participants in local forest management.

This study is based on articles published by [35-37] who dealt with questionnaire surveys among mountain bike users and assessed their preferences. Symmonds et al. [35] state that providing quality outdoor recreation and sufficient user experiences and satisfaction can only be achieved through a better understanding of the user. Koemle and Morawetz [36] also mention that the management of outdoor recreation areas requires balancing the interests of many different user groups that pursue recreation 
activities that have different characteristics, as well as groups that use the resource professionally (i.e., hunters or foresters). Making legal trails more interesting to mountain bikers may indeed relieve the pressure to sensitive areas. An elicitation of the preferences of other forest users, such as landowners or hunters, would make it possible to design a new model that accounts for the interaction and trade-offs between these user groups.

Kozumplíková et al. [38], who conducted a similar detailed survey of visitor attendance and of the preferences of cyclists for the purpose of a prepared singletrack, Písecké hory, says the following regarding game management: "the same rules apply to game management as to forest management, which means that the operator of the path network must be notified about organised hunting in advance so that the use of the path network could be restricted. Furthermore, it must be mentioned that the passing of terrain cyclists through the thick network of trails entails some negative effects in the form of potentially forcing game out to the surrounding agricultural land (animals lack peace for grazing, mating, laying eggs or care about offsprings)."

The work of Scholten et al. [39] confirms this and also partly supports the prediction that the effect of biking on deer occurrence would be higher during the day compared to night. Some studies have found an increasing avoidance of ungulates on roads or trails during the day compared to the night (Meisingset et al. in [39,40]), whereas Scholten [39] did not find an interaction between the distance to a biking trail and time (day/night). Scholten [39] found that deer avoided biking trails altogether; he also found that further than $40 \mathrm{~m}$ from a biking trail, deer occurrence slowly decreased. Deer may make a decision to cross a biking trail at a distance of around $40 \mathrm{~m}$, and thus stay longer in a place compared to further away from the biking trail, where deer experience no effect of a biking trail. However, trail width alone is not significant.

Using the example of Austria, Pröbstl-Haider et al. [41] demonstrate the complexity of the market for mountain and other forms of cycle tourism, and the pressing need to create not more trails but more sophisticated tourism products, including appealing and well-maintained trails plus attractive leisure infrastructure (bike rental, service and repair facilities, attractive localities, accommodation suited to the mountain bikers' needs, etc.).

Kozumplíková [38] states that the constructed paths should be distinguished by at least four difficulty levels in order to attract a wide target group of cyclists with varying skills, with the emphasis put on trails of low and medium difficulty, as those are important for families with children.

Yet, according to Huybers-Withers and Livingston [42], the evidence of the dominance of men in mountain biking is reflected in the images used to promote the activity. Nicolas Bowman [43], the IMBA Australia National Director said on 23 June 2018 that "many more females are riding now, mostly due to more suitable gateway trails being built and female-only rides and groups forming everywhere. One thing is clear. Toilets in the forest are important to females too. I think having some much more female-specific apparel and bikes helps a lot too."

Written communication with Greame McLean [44], the project manager of the Developing Mountain Biking in Scotland project, assumed that more women have become involved in the process of mountain bike riding training as well as in the construction of trails in Scotland, though their numbers have not risen dramatically. Mark Torsius, the CEO in IMBA Europe, provided information of the MTB (mountain bike) survey 2017 [45], filtered for females and their preferences. It follows from the results that the biggest motivation for mountain biking is the desire to enjoy nature, followed by relaxation, having fun with friends, and fitness. For women, the most important aspects for the selection of the path they will ride are the quality of the trail, technical difficulty, waymarking, nearby accommodation, car parking, and toilets, taken from the most to the least important aspects.

Based on the conclusions of their research, Getz and McConnell [46] note that because the dominant motivation for both samples, and for both men and women, was a personal challenge, it is concluded that for many respondents, involvement is directed more towards physically demanding sport than towards a particular kind of sport or event. 
Willingness to pay (WTP) was addressed by numerous authors (e.g., [47-54]), but Ja-Choon et al. [55] argue that the majority group is willing to pay for the higher cost entailed by urban forests with a higher biodiversity level and environmental education programs.

As for the length of stay of people in the forest during their visits, Janeczko and Woznicka [56] write that in the areas of urban forests in Warsaw, respondents declared most frequently that they spend between two and four hours on average per visit, and that the duration of visits depends on the size of a forest complex; the larger the forest area is, the longer the visit. Roovers et al. [57] state that the average time spent by cyclists in forests ranges from two to three hours.

\section{Materials and Methods}

\subsection{Site and Study Design}

The Training Forest Enterprise 'Masaryk Forest Krrtiny' (hereinafter referred to as the "SLP") is located northwards from Brno, where it is immediately adjacent to the city fringe and its area reaches further northwards to the town of Blansko. It has been owned by Mendel University in Brno (hereinafter referred to as "MENDELU") since 1923 when the plots belonged to the Krrtiny-Adamov manor. MENDELU got the plot under its administration for educational purposes as a "training and experimental homestead", which implies that it has been serving academic purposes since its establishment. The acreage of the forest land belonging to MENDELU accounts for 10,265 ha. It mainly serves as a place for the praxis of students and researchers. The SLP is the oldest training homestead under the umbrella of the Ministry of Education, Youth, and Sports of the Czech Republic. The recreational and touristic functions of this land also should not be forgotten. The land constitutes a thick network of paths and roads, both marked and unmarked, for pedestrian, skiing and cycle tourism [58].

The use of the interest area in the surrounding municipality of Jedovnice, as well as the local supply of services, is targeted at tourism, in particular both pedestrian and cyclo-tourism, which is mainly present thanks to the strategic position of the locality, as well as to its natural and cultural attractiveness. Many touristic destinations are situated directly in the municipality or in its close surroundings. Sports activities such as windsurfing, jet ski riding, or bike singletrails are available there for those who want to spend leisure time actively.

In the locality surrounding Jedovnice, the singletrail Moravský kras was selected for the specific survey. It is located on the left bank of the Olšovec pond in the surrounding area and it contains three circuits (path, singletrails) named according to the level of their difficulty, namely Circuit 1, Circuit 2, and Circuit 3. The main place of the premises is the Jedovnice Outpost, which serves as the entrance point for the circuits, as well as an information centre, refreshment, and repair shop. From there, bikers climb up the part of the route common for all the circuits called Stoupací (Ascending Trail) to a fork where they choose which singletrail they will take. The use of singletrails is not a subject to charge. Users can pay a voluntary fee which will be used to repair the singletrails.

The first circuit leads completely along singletrail paths. It is $10.5 \mathrm{~km}$ long and its level of difficulty is blue to red. It is the least steep and difficult circuit with obstacles suitable even for complete beginners and children. The length of the second circuit is $11.5 \mathrm{~km}$ of which $9.5 \mathrm{~km}$ leads along singletrail paths. The remaining $2 \mathrm{~km}$ leads along purpose-made paved forest roads. This path is marked as blue to red and is suitable for children. Going at their own speed, beginners will enjoy it as will advanced riders, who will use the potential of jumps and elevated curves on this trail to their full extent. The difficulty of the third circuit is marked as blue, red, and black because the difficulty of the trail will depend on the riders and their speed. The circuit is $6.5 \mathrm{~km}$ long and it is entered from a paved road. The rest of it leads along singletrail paths. It climbs up to the highest elevation of all the singletrails ( $563 \mathrm{~m}$ above the sea level) and then leads back to the entrance point, Jedovnice Outpost, with numerous curves and jumps. 
The overall length of the circuits is about $24 \mathrm{~km}$, including crossings along forest logging roads, and the length of the actual trails in the forest stand is $12.4 \mathrm{~km}$ [27]. The general orientation map is presented in the Figure 1.

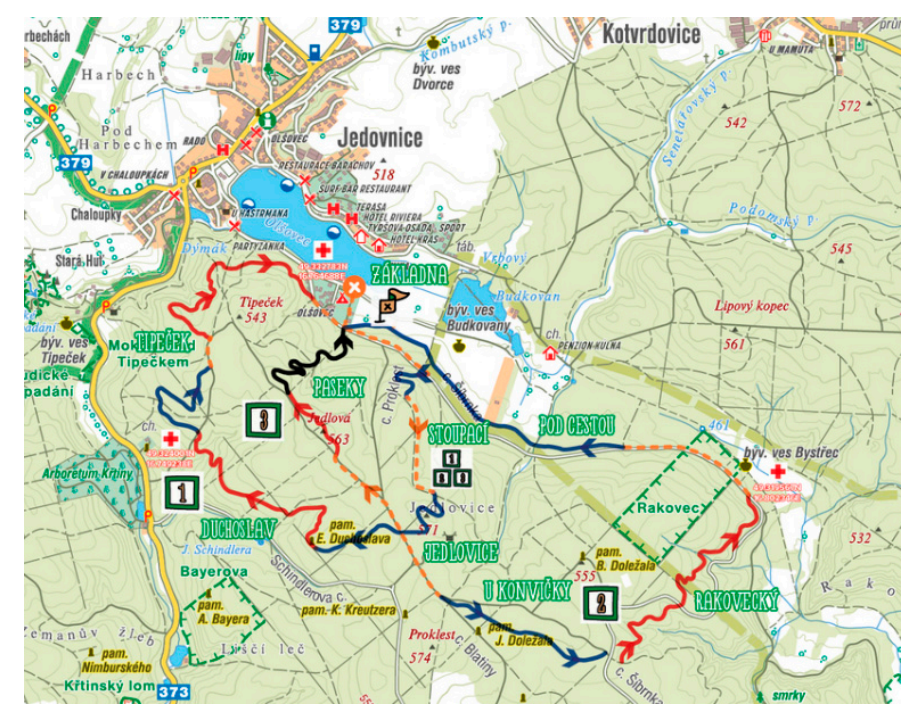

Figure 1. Orientation map of the singletrails—black, red and blue lines with arrows [59].

Regarding the technical facilities for the visitors to the singletrails, there is a parking area free of charge with the capacity of up to 500 parking places. The outpost is situated next to the parking area, which houses a repair shop, refreshments, a bike shop, and a bike rental facility. There is also a pump track next to the outpost enabling riders to test their abilities before entering the actual singletrails [32].

The visitors are obliged to observe the operational rules set for the paths. Generally, the trails must not be entered earlier than two hours after the sunrise and later than two before the sunset. An unwritten rule is that the singletrails may be entered from $8 \mathrm{am}$ to $7 \mathrm{pm}$ in the period between May to August and from 9 am to $5 \mathrm{pm}$ from September to November. The times were only stipulated this year (2018) when new parts of singletrails run by the same operator were opened in the valley of Mariánské údolí. The times are specified in the operational rules. In the case of an incidental closing of the singletrails, the users are informed in advance on social networks. Since the locality lies in the territory of the Training Forest Enterprise, field courses for students of Masaryk University in Brno are held in the locality of the singletrails, but they usually last just few days. A major restriction on entering the singletrails was the entry ban imposed by Directive of the Town of Blansko No. 7/2017 [60], which absolutely prohibited entering forests between 1 November 2017 and 30 November 2017. This ban was announced consequently to hurricane Herwart which caused major damage to the forests on 29 October 2017.

\subsection{Analysis of the Area}

\subsubsection{Analysis by Counters}

In order to monitor visitor arrivals at the singletrails of Moravský kras for the needs of the Faculty of Forestry and Wood Technology of Mendel University in Brno, Partnerství, o.p.s. installed five automatic counting devices in the surroundings of Jedovnice. The monitoring devices were installed at the end of April 2017 and the monitoring continued until November 2017. Calibration counting was performed for two days ( $16 \mathrm{~h}$ in total) during the summer season. The monitoring of visitor arrivals at the Singletrails of Moravský kras was conducted in five localities: Duchoslav, Paseky, Rakovecký, Stoupací, and Základna. These localities and specific installation sites were jointly selected with the association SINGLETRAIL Moravský kras. The mentioned localities were fitted with automatic counters which count passing of cyclists. The monitoring of visitor arrivals to the singletrails employed 
the TRAFx Trail Counter. The counter is installed under the path surface so it is not visible for people, which minimises the risk of damage and vandalism.

The monitoring on the singletrails of Moravský kras included physical calibration (manual counting of visitor arrivals) performed for two days in August 2017. Based on a comparison of the results of the manual and automatic counting, a so-called calibration coefficient was determined for the individual localities. The calibration coefficient for all the localities is $0.96-0.99$, which means that the monitoring of cyclists using automatic counters is quite exact thanks to the character of the cyclists' passages (one by one in a line).

The position of counters can be seen in the Figure 2-the map is based on the data of Strava (Heatmap [61]).

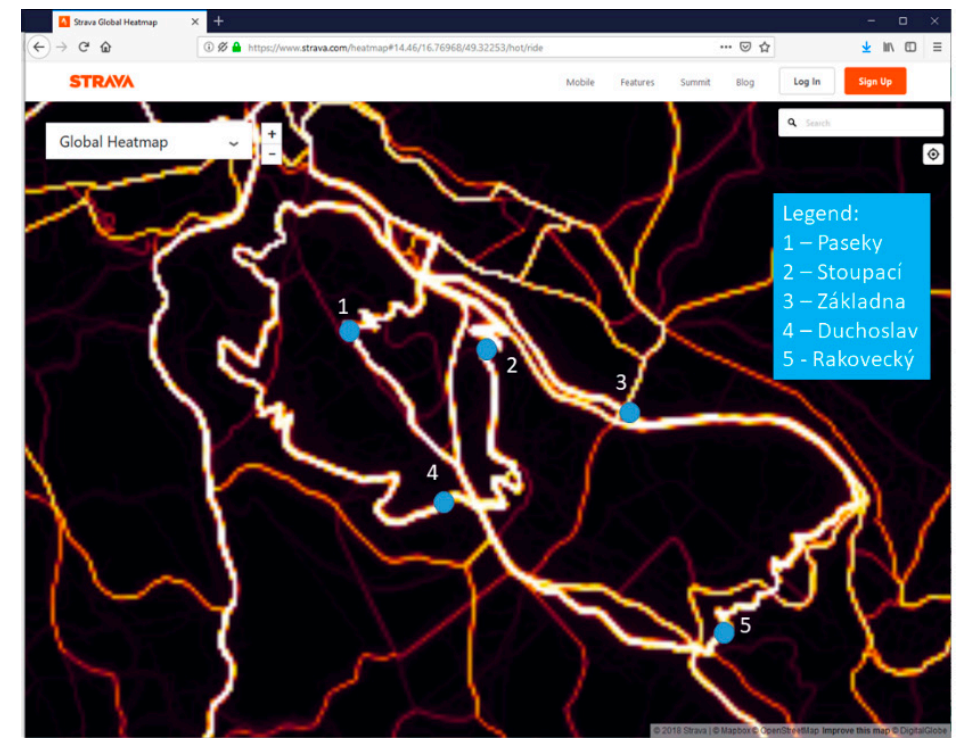

Figure 2. Heatmap of the area with places where the counters were set in the terrain (source [61] modified by authors).

The data from automatic counters provided a comprehensive view of the visitor arrivals to the singletrails. The data were analysed with respect to the potential indiscipline of the path users. All the visitors of the trails were continuously counted.

The following hypothesis has been set:

Hypothesis 1 (H1). Less than 5\% of all path users in the monitored area will use the paths outside the opening hours or during the time when entering the path is forbidden.

\subsubsection{Questionnaire Survey}

The survey was performed using written questionnaires that had been created for this purpose. All path users who passed the site at the time of distribution of the questionnaires were addressed. The actual questionnaire survey was conducted during five visits during the period between May and September 2017, when there are most tourists, i.e., potential respondents, at the locality in order to ensure the highest efficiency possible. One day each month during the weekends was chosen, and from the opening hours to closing hours all the bikers were asked to fill-in the questionnaire. The questionnaires were collected in the Jedovnice base where the bikers usually start or finish their rides. The data obtained from the questionnaire survey were subject to descriptive statistical analysis.

Among others, the data were also subject to statistical analysis with respect to the preferences of the users_-both women and men (see Table 1, see Appendix A). 
Table 1. Hypotheses (H2-H21) set for the questionnaire survey and statistical test used.

\begin{tabular}{|c|c|c|c|c|}
\hline Hypothesis & $\begin{array}{l}\text { Females and Males Have } \\
\text { the Same Preferences }\end{array}$ & Test Used & Variable's Type & Significance Level \\
\hline Hypothesis 2 (H2) & $\begin{array}{l}\text { with respect to the } \\
\text { difficulty of the individual } \\
\text { singletrails }\end{array}$ & Chi-squared test & Ordinal & $p<0.05$ \\
\hline Hypothesis 3 (H3) & $\begin{array}{l}\text { with respect to their } \\
\text { motivation which has } \\
\text { brought them to the } \\
\text { destination-contact with } \\
\text { nature }\end{array}$ & Chi-squared test & Ordinal & $p<0.05$ \\
\hline Hypothesis $4(\mathrm{H} 4)$ & $\begin{array}{l}\text { with respect to their } \\
\text { motivation which has } \\
\text { brought them to the } \\
\text { destination-training to } \\
\text { competing }\end{array}$ & Chi-squared test & Ordinal & $p<0.05$ \\
\hline Hypothesis 5 (H5) & $\begin{array}{l}\text { with respect to their } \\
\text { motivation which has } \\
\text { brought them to the } \\
\text { destination-healthy } \\
\text { movement }\end{array}$ & Chi-squared test & Ordinal & $p<0.05$ \\
\hline Hypothesis 6 (H6) & $\begin{array}{l}\text { with respect to their } \\
\text { motivation which has } \\
\text { brought them to the } \\
\text { destination-experiences } \\
\text { and adrenaline }\end{array}$ & Chi-squared test & Ordinal & $p<0.05$ \\
\hline Hypothesis 7 (H7) & $\begin{array}{l}\text { with respect to their } \\
\text { motivation which has } \\
\text { brought them to the } \\
\text { destination-friendships } \\
\text { and community }\end{array}$ & Chi-squared test & Ordinal & $p<0.05$ \\
\hline Hypothesis 8 (H8) & $\begin{array}{l}\text { with respect to their } \\
\text { motivation which has } \\
\text { brought them to the } \\
\text { destination-joy of } \\
\text { movement }\end{array}$ & Chi-squared test & Ordinal & $p<0.05$ \\
\hline Hypothesis 9 (H9) & $\begin{array}{l}\text { in the question whether } \\
\text { the singletrail is the main } \\
\text { motivation for coming into } \\
\text { the region }\end{array}$ & Chi-squared test & Ordinal & $p<0.05$ \\
\hline $\begin{array}{l}\text { Hypothesis } 10 \\
\text { (H10) }\end{array}$ & $\begin{array}{l}\text { with respect to the } \\
\text { characteristics of the paths } \\
\text { which are important to } \\
\text { them - clarity of the path } \\
\text { network }\end{array}$ & Chi-squared test & Ordinal & $p<0.05$ \\
\hline $\begin{array}{l}\text { Hypothesis } 11 \\
\text { (H11) }\end{array}$ & $\begin{array}{l}\text { with respect to the } \\
\text { characteristics of the paths } \\
\text { which are important to } \\
\text { them-path networks } \\
\text { (length of more than } 50 \\
\text { km) }\end{array}$ & Chi-squared test & Ordinal & $p<0.05$ \\
\hline $\begin{array}{l}\text { Hypothesis } 12 \\
\text { (H12) }\end{array}$ & $\begin{array}{l}\text { with respect to the } \\
\text { characteristics of the paths } \\
\text { which are important to } \\
\text { them-division of paths } \\
\text { into categories according } \\
\text { to their difficulty }\end{array}$ & Chi-squared test & Ordinal & $p<0.05$ \\
\hline
\end{tabular}


Table 1. Cont.

\begin{tabular}{|c|c|c|c|c|}
\hline Hypothesis & $\begin{array}{l}\text { Females and Males Have } \\
\text { the Same Preferences }\end{array}$ & Test Used & Variable's Type & Significance Level \\
\hline $\begin{array}{l}\text { Hypothesis } 13 \\
\text { (H13) }\end{array}$ & $\begin{array}{l}\text { with respect to the } \\
\text { characteristics of the paths } \\
\text { which are important to } \\
\text { them-long intriguing } \\
\text { downhills }\end{array}$ & Chi-squared test & Ordinal & $p<0.05$ \\
\hline $\begin{array}{l}\text { Hypothesis } 14 \\
\text { (H14) }\end{array}$ & $\begin{array}{l}\text { with respect to the } \\
\text { characteristics of the paths } \\
\text { which are important to } \\
\text { them-the destination to } \\
\text { which the paths lead }\end{array}$ & Chi-squared test & ordinal & $p<0.05$ \\
\hline $\begin{array}{l}\text { Hypothesis } 15 \\
\text { (H15) }\end{array}$ & $\begin{array}{l}\text { with respect to the } \\
\text { characteristics of the paths } \\
\text { which are important to } \\
\text { them—rolling and rocking } \\
\text { profile }\end{array}$ & Chi-squared test & ordinal & $p<0.05$ \\
\hline $\begin{array}{l}\text { Hypothesis } 16 \\
\text { (H16) }\end{array}$ & $\begin{array}{l}\text { with respect to the } \\
\text { characteristics of the paths } \\
\text { which are important to } \\
\text { them-absence of } \\
\text { dangerous terrain } \\
\text { elements }\end{array}$ & Chi-squared test & ordinal & $p<0.05$ \\
\hline $\begin{array}{l}\text { Hypothesis } 17 \\
\text { (H17) }\end{array}$ & $\begin{array}{l}\text { with respect to the } \\
\text { characteristics of the paths } \\
\text { which are important to } \\
\text { them-incorporation of } \\
\text { paths into the forest } \\
\text { environment }\end{array}$ & Chi-squared test & ordinal & $p<0.05$ \\
\hline $\begin{array}{l}\text { Hypothesis } 18 \\
\text { (H18) }\end{array}$ & $\begin{array}{l}\text { with respect to the } \\
\text { characteristics of the paths } \\
\text { which are important to } \\
\text { them-presence of difficult } \\
\text { points. }\end{array}$ & Chi-squared test & ordinal & $p<0.05$ \\
\hline $\begin{array}{l}\text { Hypothesis } 19 \\
\text { (H19) }\end{array}$ & $\begin{array}{l}\text { with respect to the } \\
\text { characteristics of the paths } \\
\text { which are important to } \\
\text { them-quality of signs and } \\
\text { maps }\end{array}$ & Chi-squared test & ordinal & $p<0.05$ \\
\hline $\begin{array}{l}\text { Hypothesis } 20 \\
\text { (H20) }\end{array}$ & $\begin{array}{l}\text { when setting the } \\
\text { percentage of travel costs } \\
\text { which they are willing to } \\
\text { pay to enter the territory }\end{array}$ & Chi-squared test & ordinal & $p<0.05$ \\
\hline $\begin{array}{l}\text { Hypothesis } 21 \\
\text { (H21) }\end{array}$ & $\begin{array}{l}\text { when setting the price of } \\
\text { the possibility to use } \\
\text { Singletrails Moravský kras }\end{array}$ & $\begin{array}{l}\text { Mann-Whitney } \\
\text { testing method }\end{array}$ & nominal & $p<0.05$ \\
\hline
\end{tabular}

The hypotheses were tested by a Chi-squared test and Mann-Whitney test. The Chi-squared test (test of goodness of fit), is generally used to test the fit of frequencies in categorical data. The Mann-Whitney test is used to compare the statistical datasets where the normal distribution of probability of the analysed characteristic cannot be assumed [62]. The assumption of the chi-square test (sample size and independence) and the Mann-Whitney $U$ test are satisfied.

\section{Results}

\subsection{Analysis by Counters}

The comparison of the monitored singletrails at Moravský kras shows a huge difference in the total number of visitor arrivals during the monitored period. Being approx. three times higher than 
in the case of the other singletrails, the visitor attendance at the singletrail Stoupací predominates significantly. This is due to the fact that this singletrail serves as the entrance to the other singletrails. Since there are also other access roads to the area of the singletrails at Moravský kras in the region of Jedovnice, cyclists use these roads, and the difference between the sum total of the singletrail Stoupací and the other singletrails accounts for approx. $40 \%$. Other singletrails show similar visitor attendance. The singletrails of Duchoslav and Základna with approx. 18,000 passages slightly differ from the singletrails of Paseky and Rakovecký with approx. 15,000 passages.

The average daily visitor attendance at the localities corresponds with the overall visitor attendance. The visitor arrivals at each locality on non-working days account for almost two thirds of the overall visitor attendance while the visitor attendance on working days stands for only one third of all the days of the period. In total, the average number of daily visitor arrivals at weekends and on public holidays was two-fold higher in than the total average daily visitor arrivals and more than 3.5-fold the average daily visitor arrivals on working days. More detailed information is provided in Table 2.

Table 2. Overall and average daily visitor attendance to the singletrails of Moravský kras in the period of 1 May-26 November 2017.

\begin{tabular}{ccccccc}
\hline \multirow{2}{*}{ Locality } & \multicolumn{2}{c}{ Overall Visitor Attendance } & \multicolumn{2}{c}{ Average Daily Visitor Attendance } \\
\cline { 2 - 6 } & All Days & $\begin{array}{c}\text { Working } \\
\text { Days }\end{array}$ & $\begin{array}{c}\text { Non-Working } \\
\text { Days }\end{array}$ & All Days & $\begin{array}{c}\text { Working } \\
\text { Days }\end{array}$ & $\begin{array}{c}\text { Non-Working } \\
\text { Days }\end{array}$ \\
\hline Duchoslav & 18,847 & 7597 & 11,250 & 90 & 53 & 170 \\
Paseky & 15,539 & 6561 & 8978 & 74 & 46 & 136 \\
Rakovecký & 15,462 & 5838 & 9624 & 74 & 41 & 146 \\
Stoupací & 44,866 & 17,461 & 27,405 & 214 & 121 & 415 \\
Základna & 17,912 & 6870 & 11,042 & 85 & 48 & 167 \\
\hline
\end{tabular}

The monitoring of visitor arrivals at the singletrails in the locality will continue in the following years so that the data can be compared.

As has already been mentioned, the opening hours of the singletrails are from 8 a.m. to 9 p.m. during the period between May and August and from 8 am to $7 \mathrm{pm}$ during the period from September to November. Furthermore, the singletrails were closed temporarily during the time of measuring using the sensors on 17 and 18 October 2017 in order to ensure the safety of the students of Masaryk University in Brno, who were conducting a field survey in the locality at that time. The singletrails were completely closed during November 2017.

The results obtained from the automatic sensors showed 6,600 illegal passages in the locality of Jedovnice. These illegal passages account for $5.9 \%$ of all passages at the singletrails. Thus, the $\mathrm{H}(1)$ hypothesis was disproved. What is alarming is the high number of passages in November- 548 in total-when the entry ban was linked to the prevention of damages to the health and property of the singletrail users. Some of these passages were done by the outpost workers, who perform daily checks of the singletrails. This would decrease the value by 26 . Having deducted the passages which could be performed after the opening hours during summer months when the Sun sets later from the total number of 6600 , the value of $2.8 \%$ illegal passages of the total number of passages is obtained. For the sake of clarity, all passages were deducted which were performed within an hour after the official closing hour since it was not stipulated explicitly until 2018. This number accounts for 3475 passages.

\subsection{Questionnaire Survey Results}

The total number of completed questionnaires is 119 . This is a sufficient number of answered questionnaires. The questionnaire survey was answered by $53 \%$ of women and $47 \%$ of men. Thus, it is quite a balanced number of addressed respondents-the proportion of our categorical variable is equal. The average age of the visitors is 33 (35 in the case of men and 30 with women). The oldest visitor to fill in the questionnaire was born in 1955. The youngest visitor who filled in the questionnaire was a woman born in 2002. It was found that $46 \%$ of visitors had completed education to the level of high 
school with graduation, and $44 \%$ to the level of university education. The average income for $30 \%$ of the respondents is between 580 and 940 EUR, for $25.3 \%$ less than 580 EUR, and for 16\% between 940 and 1300 EUR. Almost unequivocally the visitors to singletrails share the idea that the path networks named "singletrail" should have similar characteristics. The entire $71 \%$ think that they should, while $20 \%$ are not sure and only $9 \%$ answered that they should not. It follows from this result that, according to the respondents, the term "singletrail" is a mark of quality.

Only $2 \%$ of the respondents consider themselves to be beginners while $25 \%$ think that they are pre-intermediate; almost a half of the respondents (49\%) think they are intermediate and $24 \%$ think that they are experienced. The answers to this question show that most of the path users consider themselves experienced enough, which is also one of the reasons why the destination of Singletrail Moravian Karst (followed as STMK) is so visited, since there is a selection of circuits of various difficulty where both beginners and experienced bikers can pick up a difficulty which they think is suitable for them.

When determining the distance from the place of residence to the locality of singletracks, the greatest percentage of respondents $(44 \%)$ chose the answer that their place of residence is between 11 and $50 \mathrm{~km}$ from the destination. The other answers had the following proportional representation: $20 \%$ of the respondents marked the answer of $50-100 \mathrm{~km}, 17 \%$ stated $1-10 \mathrm{~km}, 11 \%$ mentioned $101-200 \mathrm{~km}, 4 \%$ above $200 \mathrm{~km}$, and 3\% less than $1 \mathrm{~km}$. This shows that most visitors to the STMK destination come travel a distance of between 11 and $50 \mathrm{~km}$, which means that the visitors are predominantly inhabitants of Central Moravia.

More than a half of the visitors (51\%) came to the destination by a motor vehicle and $38 \%$ of the respondents came on bike. Then, only few people remain who came by train $(6 \%)$, or on foot $(3 \%)$, by city public transport ( $2 \%$ ), and no one came by bus. To sum it up, $89 \%$ of visitors came either by car or on a bike, so it is very important to focus on these aspects in the future development of the locality.

Using the statistical tests we would like to analyse the differences between women's and men's preferences in order to compare what is important for both groups and what to focus on to help them to feel comfortable on the trails. The results could be useful for the trail center managers. Most bikers $(57 \%)$ prefer the path with medium difficulty (marked as red), 32\% prefer the easiest blue path, and $11 \%$ prefer the most demanding path marked with black colour. This division corresponds with the answer to the question "What type of a cyclist do you consider yourself to be?" since a half of the respondents consider themselves to be intermediate cyclists, which equals the medium difficulty of the path, while the $25 \%$ of cyclists who see themselves as pre-intermediate choose the blue path. The locality does not contain a green path, i.e., an easy singletrail with the lowest difficulty level. The $\mathrm{H}(2)$ hypothesis was disproved since the tested criterion for two degrees of freedom were exceeded significantly. Women prefer the paths of medium or lowest difficulty while males mostly prefer the path of medium difficulty, although the most difficult paths are also used.

The percentage representation of visitors according to the individual preferences shows that the joy of movement is most important for almost three quarters of bikers (65\%); experiences and adrenaline (44\%), healthy movement (52\%) and contact with nature $(39 \%)$ are of medium importance, similarly to friendships and community (38\%). In the case of the category "Training to compete", the distribution of preferences is almost even (about $20 \%$ ). It follows from the results that most respondents visit the locality because of the joy of movement, healthy movement, and experiences while the other motivations are only associated.

Hypothesis 2 (H2). Jhypothesis was disproved since the tested criterion for two degrees of freedom were exceeded significantly.

Hypothesis 3 (H3). hypothesis was proved since the testing criterion for 4 levels of freedom was not exceeded.

Hypothesis $4 \mathbf{( H 4 ) . ~ h y p o t h e s i s ~ w a s ~ d i s p r o v e d ~ s i n c e ~ t h e ~ t e s t i n g ~ c r i t e r i o n ~ f o r ~} 4$ levels of freedom was exceeded substantially. 
Hypothesis 5 (H5). hypothesis was disproved since the testing criterion for 3 levels of freedom was exceeded.

Hypothesis 6 (H6). hypothesis was disproved since the testing criterion for 3 levels of freedom was exceeded.

Hypothesis 7 (H7). hypothesis was proved since the testing criterion for 3 levels of freedom was not exceeded.

Hypothesis 8 (H8). hypothesis was disproved since the testing criterion for 3 levels of freedom was exceeded.

Contact with nature is important for both target groups. Training for competition on singletrails is not as important for women as for men, but healthy movement is very important to women, and not so much for men. Women mainly use the singletrails for the joy of movement, which is a more important reason for them than for men. Friendships are very important to both the groups.

The singletrails were the main reason for coming to the destination for $31 \%$ of visitors, $40 \%$ answered "rather yes", 20\% "rather no", and 9\% had a different main reason for visiting the locality. It can be said that the singletrails are the main reason for coming for almost three quarters of visitors to the locality of the STMK.

Hypothesis 9 (H9). hypothesis was disproved since the testing criterion for 3 levels of freedom was exceeded. The presence of the singetrail in the locality is a reason for coming there for males more than for females.

When asking about the accompanying services, the information service ranked highest, being considered the most important aspect by the respondents. They were tightly followed by parking and refreshments at the site. The list further contains services such as accommodation in a camp, repair shop, bike rental, bike wash, etc. which are considered to be of medium importance. The list is ended with training camps, a bike shop, training with an instructor, and company events. These items got almost half of the points in comparison with the information services, which means that they are considered to be less important or dispensable by the respondents. It can be concluded that, when constructing a singletrail locality, the emphasis should mainly be put on information services, parking, and refreshment as visitors see them as the most important services.

The question "Which services should not be omitted at the path networks was answered by almost $10 \%$ of the respondents. Prevailingly, but mainly with women, the answers targeted the absence of locker rooms or showers which could be used after the ride or of sanitary facilities in general (WC, showers) situated nearby the paths. The answers also included an idea to establish a source of drinking water near to the path for fast re-filling. Several respondents mentioned a lack of space for children, a playground or children corner where children could move safely.

The open question "What could be improved in relation to the paths in the STMK locality?" was answered by almost $30 \%$ of the respondents. Most often, the answers mentioned the insufficient number of parking places. Several answers, predominantly given by men, addressed the difficulty of the individual paths; according to the answers, there could be more difficult, more technical or stony sections. To sum it up, the answers differed based on the experience and demands of the individual bikers, when some of them are satisfied with the current facilities while others would prefer facilities similar to those of larger singletrail premises.

Clarity is very important (important) to most of the respondents (96\%); only $4 \%$ mentioned that it is less important to them. It can be concluded from the null proportional representation of the answers "unimportant" or "absolutely unimportant" that of all the characteristics of the paths, clarity is the really important one, and it is good to ensure it also with respect to gaining or maintaining the appeal and visitor attendance of the destination.

Hypothesis 10 (H10). hypothesis was proved since the testing criterion for 3 levels of freedom was not exceeded. 
More than a half of the respondents (57\%) saw the extent and length of the paths (more than $50 \mathrm{~km}$ ) as very important or important, $17 \%$ as unimportant or absolutely unimportant, and $25 \%$ as less important. It follows from the answers that the extent and length of the paths also play an important role among the requirements of the potential visitors on the selection of a recreation destination.

Hypothesis 11 (H11). hypothesis was proved since the testing criterion for 4 levels of freedom was not exceeded.

Hypothesis 12 (H12). hypothesis was proved since the testing criterion for 4 levels of freedom was not exceeded.

The extent of the path network with the length of more than $50 \mathrm{~km}$ and their division into circuits are important characteristics for both men and women based on which they choose the paths.

Determining the requirements of bikers on the presence of long and entertaining downhills at the destination reached the conclusion that more than a half of the respondents (56\%) think that the presence of long and entertaining downhills on singletrails is very important to important. Further, $28 \%$ of respondents see it as less important and only $16 \%$ of respondents thinks that it is unimportant or absolutely unimportant. This result clearly points to the fact that prevailingly experienced bikers come to the singletrail destinations and require more technical long downhills, and that their playfulness and entertainment is important to them.

Hypothesis 13 (H13). hypothesis was proved since the testing criterion for 4 levels of freedom was not exceeded. With this question, there was almost absolute concordance between the answers provided by men and women.

Hypothesis 14 (H14). hypothesis was disproved since the testing criterion for 4 levels of freedom was exceeded several times. But the destination of the singletrail is less important or unimportant to both men and women.

Hypothesis 15 (H15). hypothesis was disproved since the testing criterion for 4 levels of freedom was exceeded. Women consider the rolling profile to be very important to an important parameter of singletrails.

Hypothesis 16 (H16). hypothesis was disproved since the testing criterion for 4 levels of freedom was exceeded. The absence of dangerous points is less important for both men and women, yet a high percentage of the women's answers is represented by the answer very important or important.

The requirement of visitors for the incorporation of singletrails into the forest environment is very important for $34 \%$ of the respondents and important for $44 \%$ of them, which means that for most of the visitors (78\%) the incorporation into the landscape matters and that they care for the functionality and incorporation of the paths into the natural environment. This aspect is less important for $18 \%$ of the respondents only and unimportant for an almost negligible $4 \%$ of the respondents. Nobody marked the incorporation of the paths into the forest environment as unimportant, which points out to the above-mentioned fact that the incorporation into the forest environment is seen as very important.

Hypothesis 17 (H17). hypothesis was disproved since the testing criterion for 3 levels of freedom was exceeded. For women, the incorporation of the singletrails into the forest environment is a very important and important parameter of a singletrail.

The requirements of bikes for the presence of difficult points on the paths show that the difficult points are very important for $17 \%$ of the respondents, important for $29 \%$, and less important for $30 \%$. The presence of difficult points on the path is unimportant for $16 \%$ of respondents while for $8 \%$ of them it is absolutely unimportant. It can be concluded that almost half of the respondents (46\%) think that difficult points on the paths as opposed by $24 \%$ of respondents who think they are unimportant. 
Hypothesis 18 (H18). hypothesis was disproved since the testing criterion for 4 levels of freedom was exceeded. Women see the presence of difficult points in the path as less important.

The quality of marking and maps are very important for both genders, but more so for women. Further, $95 \%$ of all the path users consider the quality of marking and maps to be very important.

Hypothesis 19 (H19). hypothesis was proved since the testing criterion for 3 levels of freedom was not exceeded.

The type of refreshment which would be preferred unequivocally cannot be determined based on the answers provided by the respondents. As for food, $15 \%$ of respondents got cold refreshment for the ride, $13 \%$ got warm dishes at the entrance, $16 \%$ got refreshment at establishments during the ride, and $20 \%$ of the respondents prefer restaurants in the town. $19 \%$ preferred pub gardens while $17 \%$ preferred quality coffee. Based on these answers, it can be said that the visitors do not have an unequivocal preference and it is necessary that everybody can find at the site what they prefer.

In the case of the open question of what they recall with the word singletrail, each respondent provided their own subjective opinion; thus, the answers differ significantly. However, some words reoccur in the answers: fun, fun on bike, adrenaline, nature, bicycle, forest, relax, one-directional path. These ideas inform about the sense and objective of the whole concept of singletrails, which is the possibility of recreation in an entertaining way in nature while relaxing from the everyday stereotype.

When setting the percentage of travel costs which the visitors would be willing to pay for entering the territory, men and women accordingly set the value to $1-10 \%$. Of the total number of answers, $62 \%$ of the respondents provided this answer.

Hypothesis 20 (H20). hypothesis was proved since the testing criterion for three levels of freedom was not exceeded.

The average amount which the visitors would be willing to pay for using the singletrails was CZK 103. Men were willing to pay significantly less than women, namely CZK 78 on average while women were willing to pay CZK 125.

Hypothesis 21 (H21). hypothesis was proved since the calculated testing criterion was higher compared to the table critical value of $5 \%$ for the Mann-Whitney test.

On average, the visitors to the singletrails paid CZK 1626 for a day in the locality-men paid CZK 2254 on average while women paid CZK 1025.

\section{Discussion and Conclusions}

Singletrails, the narrow one-directional paths in nature, present a huge potential for the modern concept of cycling as well as for recreation in general. Terrain cycling offers a new perspective of bike riding, spending leisure time, and above all, of outdoor activities. The question arises of how singletrails affect the environment. Do they contribute to the development of tourism in the respective locality? First of all, the implementation of singletrails in the locality has increased the spectre of recreational possibilities, which has attracted a number of visitors who surely would not have come to the STMK territory were it not for the paths. This is supported by the fact that the STMK was the main reason for coming into the region for most of the respondents. They are mostly attracted by healthy outdoor movement and the joy it brings, which is a rare commodity in the hectic present day. Therefore, they welcome any enlivening experience into their daily lives. It has also increased the potential and attractiveness of the operators of catering facilities since most of the visitors prefer hot meals during their visits. Thus, the construction of the singletrails brings economic benefits to these establishments as well.

On the other hand, it should be remembered that the construction of singletrails in the territory of the SLP poses a commitment to provide a certain standard of services which the visitors, or bikers, are 
used to enjoying in the singletrail centres that are already in operation. Not providing these services would reduce the competitiveness of the STMK, and consequently, decrease the attractiveness of the locality for tourists. Nevertheless, the visitors assess the singletrail locality at very good level with only a few shortcomings, such as the absence of sanitary facilities missed by the female part of the population in particular, or of a place for drinking water replenishment. These services would further improve the STMK in the eyes of bikers. Another deficiency is the missing bike wash. This issue has been addressed by several authors, by Pickering et al. [63] for example, who argue that mountain bikes can collect weed seed and suggest that implementing cleaning protocols for mountain bikes will help reduce the risk of weed dispersal. Although the locality is not directly incorporated in the Landscape Protected Area of Moravian Karst, one of the trails lies just a few dozen metres from its border, and the transfer of weed seeds could have negative impacts upon it.

The respondents' answers to the open question of what the term "singletrail" connotes showed that for most people it entails fun, adrenaline, forest or relaxation.

A negative aspect is the illegal passages on the paths. Visitors are informed continuously and they can find regularly updated information on the web pages or directly at the locality. Among others, the operational rules and rules for visitors are designed to ensure the rights of game management in the territory of the SLP and to restrict passages at the times when the game is grazing and may be hunted. The assessment of passages performed in 2017 proved that the number of passages outside the opening hours of the singletrails reaches up to $5 \%$ of total number of passages through the singletrails. The number of passages at the time of the entry ban imposed by the town of Blansko following hurricane Herwart is truly alarming. There were also several passages at night, but these only account for several throughout the whole assessed period.

The recommendations may include more consistent checks of bikers who do not observe the rules. Preventive measures can also be effective in this case, i.e., providing other than restrictive information about the passing, information about the reasons why it is important to preserve the forest environment for game too, and to respect the right of safe game management, which is ensured by the Masaryk Forest Enterprise Křtiny.

Currently, a project is being implemented which partly focuses on exploring the year-to-year impact of game in the monitored territory of the STMK. The results will be published in the following years.

Although Campanelo and Mendes [28] mention other opportunities for monitoring the visitor arrivals at the paths too, monitoring using automatic counters was chosen for this survey in order to ensure the continuous monitoring of the paths and to record all passages through the trails. Not all users of the trails use new technologies and platforms which would enable the monitoring of their specific passages through the territory of the STMK.

The trails in the STMK present the main reason for coming into the region for most visitors; they usually come by motor vehicles from the place of their residence, which is within $50 \mathrm{~km}$ of the territory. The visitors are mainly cyclists who prefer medium difficulty level of the trails. According to them, the most important characteristics include the clarity of the path network and the importance of information services at the site related to it. Generally, the STMK trails are considered of sufficient quality by their visitors, to whom the term "singletrail" entails a certain standard and quality.

Women notably prefer the medium to the easiest level of difficulty of the trails while men mainly prefer the trails of medium difficulty, although they use the most difficult trails, too.

The contact with nature is important for both the target groups. Training on singletrails is not that important for women as for the men, but the healthy movement is very important to them. Women mainly ride on the singletrails for the joy of movement, which they consider to be a more important reason than men. Spending time with friends is considered either important or very important by both the groups. The singletrails are the reason for coming to the locality for more men than women. Both men and women think that the destination at the end of the singletrail either less important or unimportant. For women, the rolling profile is an important or very important parameter of singletrails. According to Heer et al. [64] and Symmonds et al. [65] the survey indicates a moderate to strong 
ecological concern to the environment. Symmonds et al. [65] also states that the bikers prefer natural rather than artifical material in the construction.

The absence of dangerous points is of less importance to both men and women, yet a large percentage of answers provided by women is represented by the answer "very important" or "important". Nobody has marked the incorporation of the paths into the forest environment as unimportant, which supports the above-mentioned fact that the incorporation of the paths into the forest environment is considered to be very important. For women, the incorporation of the paths into the forest environment is an important or very important to parameter of singletrails. Goeft and Alder [66] mention the preferences for trails in natural settings as well.

Women also see the presence of dangerous points at the track to be a less important issue. For both genders, the quality of marking and the quality of maps are very important, but they are of greater importance to women than men. The quality of marking and the quality of maps are very important to important to $95 \%$ of all the users of the singletrails.

The average sum which the visitors would be willing to pay for the use of singletrails accounts for CZK 103.00. Men are willing to pay significantly less than women, namely CZK 78.00 and CZK 125.00 on average, respectively. On average, men spent CZK 2254.00 per day in the locality while women spent CZK 1025.00. That implies that women are more willing to pay a bigger sum for the use of singletrails per se than men, while men spent more money in the locality on average than women. Taking the example of Slovenia, Zajc and Berzelak [66] demonstrate that bikers are not willing to pay fees to ride on trails in natural areas. However, they express a high willingness to voluntarily participate in trail maintenance activities. Data obtained from the Forestry Commission Scotland [67] show that three-quarters of visitors to Scotland's national forest estate who take part in cycling or mountain biking are male ( $76 \%$ ). The average age of visitors to the forest who take part in cycling and mountain biking is 32 . About $17 \%$ of visitors to forest who take part in cycling or mountain biking have children in their party. The average distance travelled by cyclists/mountain bikers is 27 miles (approximately $43.2 \mathrm{~km}$ ). On average, forest visitors who take part in cycling and mountain biking spend $£ 26$ (approximately $760 \mathrm{CZK}$ ) during their trip. The preferences in some aspects show us that the managers of the area should think about and focus on the specific public relations and advertisements-specifically for women and men. Women prefer the health and training, meeting with friends and the joy of the movement. Images on the internet and in marketing materials can attract women to the area. This can work with the information about the clarity of the path network and with information about the lines without dangerous terrain elements. Women highly prefer the incorporation of paths into the forest environment. It goes hand in hand with environmental protection [66] and the sustainable management of the area. For men, the most important aspect is the competition.

Thanks to the abundant recreational possibilities, including bike paths, the recreational potential of the STMK destination is at a very good level. However, the demands of the public must still be taken into account and efforts should be made to further improve and refurbish the locality in order to prevent stagnation, which would result in a drop in visitor interest and attendance.

Author Contributions: Conceptualization, J.F. and D.B.; methodology, J.F.; validation, J.F., D.B. and J.M.; investigation, N.Ž.; resources, N.Ž.; data curation, J.M; writing—original draft preparation, J.F.; writing—review and editing, I.M.; supervision, I.M.; project administration, D.B.; funding acquisition, J.M.

Funding: This research was funded by Internal Grant Agency Mendel University in Brno, grant number LDF_VT_2017006 and funded by the Ministry of Agriculture of the Czech Republic, Project No. QK1820358.

Acknowledgments: We would like to thank Tomáš Kvasnička from Singletrack, s.r.o. for his help in contacting the important personalities of mountain biking throughout the world.

Conflicts of Interest: The authors declare no conflict of interest.

\section{Appendix A}

The questions which were asked, and which form the basis for the hypotheses, were the following: 
Which of the following motivations brought you the destination of the singletrail paths? (very important, important, less important, unimportant, very unimportant)

- Contact with nature

- Training to competing

- Healthy movement

- Experiences and adrenaline

- Friendship and community

- Joy of movement

Is the singletrail the main reason why you have come to the destination? (yes, rather yes, rather no, no)?

Which characteristics of the MTB path network are important to you? (very important, important, less important, unimportant, very unimportant)

- Clarity of the path network

- Extent of the path network (length of more than $50 \mathrm{~km}$ )

- Division of paths into circuits according to the level of their difficulty

- $\quad$ Long intriguing downhills

- Destinations to which the paths lead

- $\quad$ Rolling and rocking profile

- Absence of dangerous terrain points

- Incorporation of the paths into the forest environment

- Presence of difficult points

- Quality of signs and maps

What percentage of your travel costs would you be willing to pay for the entry to this territory if user fees were introduced? $(0,1-10,11-30,31-50,51-75,75-100$, more)

At which sum of money assess the possibility to use the STMK paths?

\section{References}

1. Schneider, J.; Fialová, J.; Vyskot, I. Krajinná Rekreologie I [Landscape Recreology I.]; Mendel University in Brno: Brno, Czech Republic, 2008; p. 140. ISBN 978-80-7375-200-2.

2. Ministry of the Environment of the Czech Republic. Act Nr. 289/1995 Coll. On Forests and on Alterations to some Acts; Ministry of the Environment of the Czech Republic: Praha, Czech Republic, 1995.

3. Martin, R.; Butler, D.R.; Klier, J. The influence of tire size on bicycle impacts to soil and vegetation. J. Outdoor Recreat. Tour. 2018, 24. [CrossRef]

4. Hrůza, P.; Zemanek, T. The Influence of Singletrail Construction on the Soil Profile. In Public Recreation and Landscape Protection -With Nature Hand in Hand! Mendel University in Brno: Brno, Czech Republic, 2018; pp. 348-352. ISBN 978-80-7509-550-3.

5. Flora, M. Rekreační Účinky Lesních Ekosystémů [Recreational Impacts of Forest Ecosystems]; Mendel University in Brno: Brno, Czech Republic, 2017; p. 124. ISBN 978-80-7509-506-0.

6. Gökovali, U.; Bahar, O. Contribution of tourism to economic growth: A panel data approach. Anatolia 2006, 17, 155-167. [CrossRef]

7. Ivanov, S.H.; Webster, C. Tourism's contribution to economic growth: A global analysis for the first decade of the millennium. Tour. Econ. 2013, 19, 477-508. [CrossRef]

8. Katircioglu, S.T. Revisiting the tourism-led-growth hypothesis for Turkey using the bounds test and Johansen approach for cointegration. Tour. Manag. 2009, 30, 17-20. [CrossRef]

9. Lew, A.A. Tourism's role in the global economy. Tour. Geogr. 2011, 13, 148-151. [CrossRef]

10. Tang, C.F.; Abosedra, S. The impacts of tourism, energy consumption and political instability on economic growth in the MENA countries. Energy Policy 2014, 68, 458-464. [CrossRef] 
11. Barros, A.; Gonnet, J.; Pickering, C. Impacts of informal trails on vegetation and soils in the highest protected area in the Southern Hemisphere. J. Environ. Manag. 2013, 127, 50-60. [CrossRef]

12. Marzano, M.; Dandy, N. Recreationist behaviour in forests and the disturbance of wildlife. Biodivers. Conserv. 2012, 21, 2967-2986. [CrossRef]

13. Newsome, D. Appropriate policy development and research needs in response to adventure racing in protected areas. Biol. Conserv. 2014, 171, 259-269. [CrossRef]

14. Oian, H. Wilderness tourism and the moralities of commitment: Hunting and angling as modes of engaging with the natures and animals of rural landscapes in Norway. J. Rural Stud. 2013, 32, 177-185. [CrossRef]

15. Daldeniz, B.; Hampton, M.P. Dive tourism and local communities: Active participation or subject to impacts? Case studies from Malaysia. Int. J. Tour. Res. 2013, 15, 507-520. [CrossRef]

16. Thomas, F.; Kapoor, A.; Marshall, P. Tourism development and behavioural changes: Evidences from Ratanakiri province, Kingdom of Cambodia. J. Tour. Cult. Chang. 2013, 11, 208-219. [CrossRef]

17. Williams, S. Tourism Geography; Routledge: London, UK, 2000.

18. Butler, R.W. The concept of a tourist area cycle of evolution: Implications for management of resources. Can. Geogr. Geogr. Can. 1980, 24, 5-12. [CrossRef]

19. Hardin, G. The tragedy of the commons. Science 1968, 162, 1243-1248. [PubMed]

20. Hall, C.M.; Frost, W. Introduction: The Making of the National Parks Concept. In Tourism and National Parks: International Perspectives on Development, Histories, and Change; Routledge: London, UK, 2009; pp. 3-15.

21. Holden, A. Environment and Tourism; Routledge: London, UK, 2000.

22. Zahradník, D.; Banas, M.; Jirásková, E. Back and front of visitor monitoring-Examples of good and less successful visitor monitoring in the Czech protected areas. J. Landsc. Manag. 2012, 3, 14-19.

23. Bláha, P. Výsledky monitorování a jejich využití v praxis—Liberecký kraj [Monitoring Results and their Use in Practice-The Region of Liberec]. Ochrana Př́rody 2010. (Special Issue).

24. Kala, L.; Salov, T. Výsledky monitorování a jejich využití v praxis-České Švýcarsko [Monitoring Results and their Use in Practice-The Bohemian Switzerland]. Ochrana Př́rody 2010. (Special Issue).

25. Kos, J. Výsledky monitorování a jejich využití v praxis—Národní park Podyjí. [Monitoring Results and their Use in Practice-The National Park of Podyjí]. Ochrana Př́rody 2010. (Special Issue).

26. Kopecka, V.; Machar, I.; Bucek, A.; Kopecky, A. The Impact of Climate Changes on Sugar Beet Growing Conditions in the Czech Republic. Listy Cukrovarnicke a Reparske 2013, 129, 326-329.

27. Fialová, J.; Kupec, P.; Hlaváčková, P.; Šafarik, D. Visitor monitoring of selected trails in ŠLP Křtiny. In Public Recreation and Landscape Protection-With Man Hand in Hand? Mendel University in Brno: Brno, Czech Republic, 2014; pp. 340-343.

28. Campelo, M.B.; Nogueira Mendes, R.M. Comparing webshare services to assess mountain bike use in protected areas. J. Outdoor Recreat. Tour. 2016, 15, 82-88. [CrossRef]

29. Mourek, D. Cykloturistika: Současný stav a perspektivy v České republice [Cyclo-tourism: Current State and Perspectives in the Czech Republic]. Prague Czech Tourism 2011, 129.

30. Mimoprodukční Funkce Lesa Cyklistika v Lesních Majetcích. Available online: http://docplayer.cz/4729685Mimoprodukcni-funkce-lesa-cyklistika-v-lesnich-majetcich.html (accessed on 15 March 2018).

31. Martinek, J. 21 Pilírů pro Cyklistickou Infrastrukturu [The 21 Pillars for Cycling Infrastructure]; Transport Research Centre: Brno, Czech Republic, 2007; p. 70.

32. O Trailech. Available online: http://singlekras.cz/o-trailech (accessed on 10 March 2018).

33. Náročnost Stezek. Available online: http://www.vysocina.bike/singletracky/narocnost-stezek/ (accessed on 10 March 2018).

34. Hirano, Y. New challenges and possibilities of forest use by mountain bikers. J. Jpn. For. Soc. 2016, 98, 1-10. [CrossRef]

35. Symmonds, M.C.; Hammitt, W. Managing Recreational Trail Environments for Mountain Bike User Preferences. Environ. Manag. 2000, 25, 549-564. [CrossRef] [PubMed]

36. Koemle, D.A.B.; Morawetz, U.B. Improving mountain bike trails in Austria: An assessment of trail preferences and benefits from trail features using choice experiments. J. Outdoor Recreat. Tour. 2016, 15, 55-65. [CrossRef]

37. Studie Proveditelnosti Záměru Projektu Singltrek Písecké Hory. Available online: http://www.mesto-pisek. cz/assets/File.ashx?id_org=12075\&id_dokumenty=8557 (accessed on 15 May 2018).

38. Pickering, C.M.; Rossi, S. Mountain biking in peri-urban parks: Social factors influencing perceptions of conflicts in three popular National Parks in Australia. J. Outdoor Recreat. Tour. 2016, 15, 71-81. [CrossRef] 
39. Scholten, J.; Moe, S.R.; Hegland, S.J. Red deer (Cervus elaphus) avoid mountainbiking trails. Eur. J. Wildl. Res. 2018, 64, 9. [CrossRef]

40. Godvik, I.; Loe, L.E.; Vik, J.O.; Veiberg, V.; Langvatn, R.; Mysterud, A. Temporal scales, trade-offs, and functional responses in red deer habitat selection. Ecology 2009, 90, 699-710. [CrossRef]

41. Pröbstl-Haider, U.; Lund-Durlacher, D.; Antonschmidt, H.; Hödl, C. Mountain bike tourism in Austria and the Alpine region-Towards a sustainable model for multi-stakeholder product development. J. Sustain. Tour. 2018, 26, 567-582. [CrossRef]

42. Huybers-Withers, S.M.; Livingston, L.A. Mountain biking is for men: Consumption practices and identity portrayed by a niche magazine. Sport Soc. 2010, 13, 1204-1222. [CrossRef]

43. Bowman, N.; Director in Destination Trails Pty Ltd, Trail Specialist, Adelaide, Australia. Personal communication-e-mail, 23 June 2018.

44. McLean, G.; Head of Developing Mountain Biking in Scotland, Edinburgh, United Kingdom. Personal communication-e-mail, 28 June 2018.

45. Van Schijndel, J. European MTB Survey 2017; Report filters-Gender: Female. Provided by Mark Torsius (CEO IMBA Europe); IMBA Europe: Veenendaal, The Netherlands, 2018.

46. Getz, D.; McConnell, A. Comparing Trail Runners and Mountain Bikers: Motivation, Involvement, Portfolios, and Event-Tourist Careers. J. Conv. Event Tour. 2014, 15, 69-100. [CrossRef]

47. Ajzen, I.; Driver, B.L. Contingent value measurement: On the nature and meaning of willingness to pay. J. Consum. Psychol. 1992, 1, 297-316. [CrossRef]

48. Barro, S.C.; Manfredo, M.J.; Brown, T.C.; Peterson, G.L. Examination of the predictive validity of CVM using an attitude-behavior Framework. Soc. Nat. Resour. 1996, 9, 111-124. [CrossRef]

49. Hanley, N.; Wright, R.; Adamowicz, V. Using choice experiments to value the environment. Environ. Resour. Econ. 1998, 11, 413-428. [CrossRef]

50. Rollins, R.; Trotter, W. Public attitudes regarding user fees in provincial forest lands. Leisure/L. J. Can. Assoc. Leis. Stud. 2000, 24, 139-159.

51. Watson, D.O.; McFarlane, B.L.; Haener, M.K. Human dimensions of biodiversity conservation in the interior forests of British Columbia. J. Ecosyst. Manag. 2004, 4, 1-20.

52. Horne, P.; Boxall, P.C.; Adamowicz, W.L. Multiple-use management of forest recreation sites: A spatially explicit choice experiment. For. Ecol. Manag. 2005, 207, 189-199. [CrossRef]

53. Bernath, K.; Roschewitz, A. Recreational benefits of urban forests: Explaining visitors' willingness to pay in the context of the theory of planned behavior. J. Environ. Manag. 2008, 89, 155-166. [CrossRef]

54. Rosenberger, R.S.; Needham, M.D.; Morzillo, A.T.; Moehrke, C. Attitudes, willingness to pay, and stated values for recreation use fees at an urban proximate forest. J. For. Econ. 2012, 18, 271-281. [CrossRef]

55. Ja-Choon, K.; Mi Sun, P.; Yeo-Chang, Y. Preferences of urban dwellers on urban forest recreational services in South Korea. Urban For. Urban Green. 2013, 12, 200-210. [CrossRef]

56. Janeczko, E.; Woźnicka, M. Zagospodarowanie rekreacyjne lasów Warszawy w kontekście potrzeb i oczekiwań mieszkańców stolicy. Studia i Materiały Centrum Edukacji Przyrodniczo-Leśnej 2009, 4, 131-139.

57. Roovers, P.; Hermy, M.; Gulinck, H. Visitor profile, perceptions and expectations in forest from a gradient of increasing urbanization in central Belgium. Landsc. Urban Plan. 2002, 59, 129-145. [CrossRef]

58. ŠLP Křtiny-O nás. Available online: http://www.slpkrtiny.cz/slp-krtiny/o-nas/ (accessed on 12 January 2018).

59. Jedovnické stezky—SINGLETRAIL Moravský Kras. Available online: https://singlekras.cz/jedovnicke-stezky (accessed on 12 June 2019).

60. Directive of the Town of Blansko No. 7/2017 which Declares the Entry Ban on the Forests in the Administrative Area of the Municipality with Extended Authority of Blansko. Available online: http://www.mestyscernahora. cz/assets/File.ashx?id_org=1982\&id_dokumenty=5384 (accessed on 15 May 2018).

61. Strava Global Heatman. Available online: www.strava.com/heatmap\#14.46/16.76968.49.32253/hot/ride (accessed on 12 January 2019).

62. Pecáková, I. Statistics in Field Research. In Czech: Statistika v Terénních Průzkumech; 2nd revised and expanded ed.; Kamil Mařík—Professional Publishing: Příbram, Czech Republic, 2011; p. 236. ISBN 978-80-7431-039-3.

63. Pickering, C.; Ansong, M.; Wallace, E. Experimental assessment of weed seed attaching to a mountain bike and horse under dry conditions. J. Outdoor Recreat. Tour. 2016, 15, 66-70. [CrossRef]

64. Heer, C.; Rusterholz, H.P.; Baur, B. Forest perception and knowledge of hikers and mountain bikers in two different areas in northwestern Switzerland. Environ. Manag. 2003, 31, 709. [CrossRef] 
65. Goeft, U.; Alder, J. Sustainable mountain biking: A case study from the south-west of Western Australia. J. Sustain. Tour. 2001, 9. [CrossRef]

66. Zajc, P.; Berzelak, N. Riding styles and characteristics of rides among Slovenian mountain bikers and management challenge. J. Outdoor Recreat. Tour. 2016, 15, 10-19. [CrossRef]

67. Cycling and Mountain Biking in Forest, Result from All Forest Survey 2-2013. Available online: https://scotland.forestry.gov.uk/images/corporate/pdf/all-forests-survey-2013-cyclists-and-mountainbikers-factsheet.pdf (accessed on 28 June 2018).

(C) 2019 by the authors. Licensee MDPI, Basel, Switzerland. This article is an open access article distributed under the terms and conditions of the Creative Commons Attribution (CC BY) license (http://creativecommons.org/licenses/by/4.0/). 